\title{
変敗缶詰食品功分離した偏性嫌気性 有芽胞細菌の簡易法による同定
}

\author{
松田典彦*・駒木 勝*・市川良子*・後藤幸恵*
Facultative Anaerobic Spore-forming Bacteria Isolated from Spoiled Canned Foods

\author{
Norihiko Matsuda*, Masaru KomakI*, Ryohko Ichikawa* \\ and Sachie Goтoн* \\ - Research Laboratory, Japan Canners Association, \\ 460 Kariba-cho, Hodogaya-ku, Yokohama 240
}

\begin{abstract}
Isolates from spoiled canned foods were identified. Since many isolates did not represent typical biological characteristics as shown in text books, the simplified method was employed to identify them. Among 122 strains examined, 99 strains (81\%) could be identified as follows; Clostridium sporogenes, 65; C. thermosaccharolyticum, 14; C. pasteurianum, 11; Desulfotomaculum nigrificans, 4; C. butyricum, 3 and $C$. perfringens, 2 . Ten of 23 strains remained were identified as C. thermoaceticum, but 13 strains could not be assigned. The simplified formulae table was proposed for differential identification of commonly encountered species of genera Clostridium and Desulfotomaculum in canned food spoilage. The table enable to identify the organism according to the limited biological characteristics, i. e., optimum growth temperature, aerobic growth, morphology of a spore and a sporangium, productions of lecithinase and lipase, fermentation and digestion of milk, and production of acid from starch, production of toxin or reduction of sulfate as occasion demands.
\end{abstract}

(Received Aug. 28, 1984)

年詰食品の镫生物による变敗は，多くの場合，加熱殺 菌が不足したため年内に生き残ったか，あるい愹器の 密封が不完全であったために加熱殺菌後に缶内に侵入し た锁生物が発育した結果ひき起される。加熱殺菌不足に より変敗した年詰食品からは有芽胞練菌が分略されるこ とが多いが、これらの種を同定することは，变敗事故の 再発防止と，加熱殺菌条件設定のための手掛りを得るの に役立つ。

著者らは，变敗缶詰由来有第胞細菌の生物学的性状を 調へ, BergeY's Manual (第 8 版) ${ }^{11}$ 亿従い同定を試及 たか，非定型的性状を示寸菌株が多く同定が困蜼であっ た。そこで，限られた性状に基つく簡易爁別法を詰みた ところ，良い成樍を得たので報告する。本報ては偏性姬 気性稩菌について述べる。

\section{実験 方 法}

\section{1. 供試菌株}

前報21で分離した偏性嫽気性有芽胞細菌及び 1967 年 以前に当研究所で分離し，保存中の変敗缶詰由来の同上 細菌, 合計 122 株を用いた。

2. 培地の調製

(1) 肝肝ブイョン培地

豚肝蔵 $300 \mathrm{~g}$ を边約 $5 \mathrm{~cm}$ に的切りし，脱イオン ホ $1 l$ を加之，約 1 時間沸脸させた。令却啳，脱脂綿を ガーゼで包んだフィルターで口過し，粗大粒子を除歨し た。肝䠄は水洗後, 水を切り, 一辺約 $5 \mathrm{~mm}$ K角切りし た。 ヘクト・ペブトン(Difco) $10 \mathrm{~g}$, 酻エキス（大五栄

*（社）日本岳詰協会・研究所（广 240 横捠市保土ヶ谷区狩場町 460 番地） 
養化学) $3 \mathrm{~g}$, ブドゥ糖 $5 \mathrm{~g}$, 可溶珄デンプン $1 \mathrm{~g}$, リ

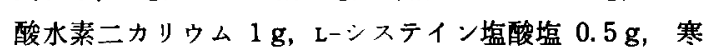
天 $1.5 \mathrm{~g}$ を上記の肝葴浸出口液 $1 l$ に加熱溶解後, $\mathrm{pH}$ 7.8 に調整した。

中試験管（ねじ蓋付，外径 $16 \mathrm{~mm}$, 長さ $150 \mathrm{~mm}$ ) に 肝臓片 4 5 個及び炭酸カルシウム約 $0.1 \mathrm{~g}$ (薬匙小 1 杯）を投入し，前記の液を約 $10 \mathrm{~m} l$ ずつ分注した。 121 ${ }^{\circ} \mathrm{C} ， 20$ 分間高生隇菌した。

菌株保存用培地とするときには，炭酸カルシウムの代 りに, 土壤と炭酸カルシゥムとの混合末約 $0.1 \mathrm{~g}$ を試験 管に投入した。

(2) 土堷と炭酸カルシウムとの混合末3)

当研究所敷地内の土㙵を乾燥し, メッシュ $3 \sim 4 \mathrm{~mm}$ の篮を通した。この土と炭酸カルシウムを重量比約 9:1 の割合で混合した後、アルミ製盆上に厚さ約 $5 \mathrm{~mm}$ に拆 げ，乾熱で $160^{\circ} \mathrm{C}, 3$ 時間，3回間歇減菌した。

(3) GAM 半流動及び寒天培地

日水製薬(株)製を用いた。たたし，寒天培地には寒天 5 g/l を加えた。

(4) PE-2 培地4)

ハクト・ペプトン $5 \mathrm{~g}$ ，酵母エキス $5 \mathrm{~g}$, L-システイ ン塩酸塩 $0.5 \mathrm{~g}$, 寒天 $1.5 \mathrm{~g}$ を脱イオン水 $1 l$ に加熱溶 解した。 pH は調整しなかった。中試験管に乾燥エンド ウ豆 (アラスカ種) $3 \sim 4$ 粒及び炭酸カルシウム約 0.1 $\mathrm{g}$ を投入し，上記の液を約 $10 \mathrm{~m} l$ ずつ分注した。 $121^{\circ} \mathrm{C}$ ， 20 分間高压隇菌した。

\section{(5) ブドウ糖寒天培地}

肉エキス (極東製薬) $2 \mathrm{~g}$ ，酵母ェキス $3 \mathrm{~g}$ ，ペプトン (Difco または大五栄養化学) $10 \mathrm{~g}$, ブドウ精 $5 \mathrm{~g}$, 塩化 ナトリゥム $5 \mathrm{~g}$, 寒天 $20 \mathrm{~g}$ を脱イオン水 $1 l$ に加熱溶 解し, pH 7.0 に調整し, $121^{\circ} \mathrm{C}, 20$ 分間高圧隇菌した。 隇菌ペトリ血に適量分注し，平板に固化し用いた。

(6) ゼラチン培地

プロテオース・ペプトン (Difco) $10 \mathrm{~g}$ ，酵母ェキス $10 \mathrm{~g}$, ブドウ糖 $10 \mathrm{~g}$, 塩化ナトリウム $5 \mathrm{~g}$, ゼラチン末 $100 \mathrm{~g}$, L-ンスティン塩酸塩 $0.5 \mathrm{~g}$ を脱イオン水 $1 l$ K 加熱溶解し， pH 7.0 に調整した。これらを小試験管 (ねじ算付, 外径 $13 \mathrm{~mm}$, 長さ $100 \mathrm{~mm}$ ) に $5 \mathrm{ml}$ ずつ 分注し, $121^{\circ} \mathrm{C}, 15$ 分間帛生減菌した。

(7) 卵黄寒天培地

培地びんに GAM 寒天培地 $450 \mathrm{~m} l$ を分注し, 隇菌し ておいた。使用時にこれを加熱溶解し， $55^{\circ} \mathrm{C}$ に保温し た。

ペつに $100 \mathrm{~m} l$ 容ビーカーに生理食塩水 $20 \mathrm{~m} l$ とマグ
ネチック・スターリング・ベー（テフロン被覆）1本を 入れ、フルミホイルで覆って， $121^{\circ} \mathrm{C} ， 15$ 分間高圧隇菌 して扣き,これに生鮮啋即 1 個の即黄を無菌的に加兄， マダネチック・スターラーで, 気泡ができないよ5に注 意しながら，混和した。

これをマグネチック・スターリング・バーとともに GAM 寒天培地に加え, 同様に混和した後, 隇菌ペトリ 皿に適量分注し，平板に固化し用いた。

本培地は調製後ただちに用い，しばらくおくときには 嫌気的 (BBL，GasPak を使用) に保存した。

(8) 凝固卵白培地

鶏卵 1 個の即白を $200 \mathrm{~m} l$ 容ビーカーにとり, 沸腾木 中で 30 分間加熱し，凝固させた。これを一辺約 $5 \mathrm{~mm}$ に角切りし，その $2 \sim 3$ 片を小試験管に投入L, GAM 半流動培地を $5 \mathrm{ml}$ ずつ分注した。 $121^{\circ} \mathrm{C}, 15$ 分間高压珹 菌した。

\section{(9) 鉄加牛乳培地 ${ }^{51}$}

無メッキ鉄くぎ（長さ約 $3 \mathrm{~cm}$ ）を $0.1 \mathrm{~N}$-塩酸液に約 30 分間浸漬した後, 水洗した。

小試験管に牛乳 $5 \mathrm{~m} l$ ずつを分注し，鉄くぎ 1 本を投 入した。 $121^{\circ} \mathrm{C}, 15$ 分間高圧隇菌した。

(10)炭水化物分解試験用培地

プロテオース・ペプトン $10 \mathrm{~g}$, 酵母ェキ $10 \mathrm{~g}$, 塩 化ナトリウム $5 \mathrm{~g}, \mathrm{~L}-シ$ シイン塩酸塩 $0.5 \mathrm{~g}$, 寒天 1.5 $\mathrm{g}$ を脱イオン水 $1 l$ K加熱溶解し, $\mathrm{pH} 7.2$ K調整し た。この $90 \mathrm{~m} l$ ずつを培地びんに分注し、マグネチッ ク・スターリング・ハー1 1本を投入した。 $121^{\circ} \mathrm{C}, 15$ 分 間高王隇菌した。

プドゥ糖, マンノース及び乳糖では，それぞれ，口過 隇菌した $10 \%$ 水溶液 $10 \mathrm{~m} l$ を前記培地に無菌的に加光， マク゚ネチック・スターラーでよく混和した後, 减菌小試 験管に無菌的に $5 \mathrm{~m} l$ ずつ分注した。デンプンでは，前 記の培地組成に可溶性デンプン $10 \mathrm{~g}$ を直接加えた。

(11) クックド・ミート培地

中武験管に乾燥クックド・ミート培地 (Difco) 約 $1 \mathrm{~g}$ を投入し， $0.1 \%$ 寒天液 $10 \mathrm{ml}$ を分注した。 $121^{\circ} \mathrm{C}, 15$ 分間高圧隇菌した。

\section{(12) 硫酸塩培地 ${ }^{6)}$}

リン酸二水素カリウム $0.5 \mathrm{~g}$, 塩化アンモニウム $1 \mathrm{~g}$, 硫酸ナトリウム $1 \mathrm{~g}$, 塩化カルシウム (2水塩) $0.1 \mathrm{~g}$, 硫酸マグネシウム（7 水塩） $2 \mathrm{~g}$ ，乳酸ナトリウム 3.5 $\mathrm{g}$ ，醰块ス $1 \mathrm{~g}$ を脱イオン水 $1 l$ に加熱溶解し， $\mathrm{pH}$ 7.6 に調整した。 $121^{\circ} \mathrm{C} ， 20$ 分間高圧隇菌した後この 液を口紙（東洋滤紙，No. 101）で口過して沈殷物を除 
去した。冷却後，寒天 $1 \mathrm{~g} / l$ を加え，加熱容解した。こ の $500 \mathrm{~m} l$ 才゙つを培地びんに分注し、マグネチック・ス ターリンク・ハー 1 本を投入し， $121^{\circ} \mathrm{C} ， 20$ 分間高压减

菌した。

命却後，口過隇菌した $1 \%$ 硫酸第一鉄フンモニウム液 $50 \mathrm{~m} l / l$ を無菌的に加え, マグネチックスターラーで

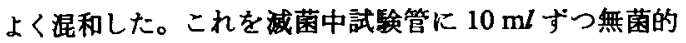
に分注した。

本培地は調製後 2 日以内に用いた。

\section{3. 菌株の保存}

保存培責液 $0.5 \mathrm{ml}$ を隇菌パスッール・ビベットでと ク，あらかじめ沸腾水中で 20 分間加熱脱気して扰いた 䀒肝プイヨン培地（土壤と炭酸カルシウム添加）の底部 に接種した。この培地を沸腍水中で 5 分間，またはこの 条件で死珹する菌株では $80^{\circ} \mathrm{C} ， 20$ 分間加熱処理して芽 胞を活性化した媵，中温性細菌は $35^{\circ} \mathrm{C} ， 15$ 日間，高温 性細菌は $55^{\circ} \mathrm{C} ， 10$ 日間培盖した。これらは密怪後室温 で保存し， 1 年ごとに植え継いた。

\section{4. 生物学的性状試験}

以下の試験ではとくに記さない限り, 次の要領によっ た。すなかち，半流動培地は使用前に沸腾水中で 20 分 間加熱脱気し，冷却しておいた。この 底部に 前培責液 $0.1 \sim 0.5 \mathrm{~m} l$ を减菌パスッール・ピペットで接種し, 発

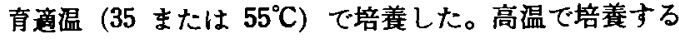
とき，及び低温でも長期間培着するときには，乾嬠を防 止するため密栓した。

\section{(1) 前培}

供試菌株の培盖液を適当な半流動培地（主としてGAM 半流動培地これに発育しないすのは PE-2 培地または 旰肝ブイョン培地) に接種した。栄養細胞を殺堿し，芽 胞を活性化するため，これを $80^{\circ} \mathrm{C} ， 20$ 分間加熱した啳， 1夜培盖した。発育しないものは旺盛な発育が認められ るまで (通常 $2 \sim 3$ 日間) 培養した。

\section{(2) 好気的発育}

ブドウ榶寒天平板培地に前培養液 1 白金耳を画線し， 5 日間培羕した。

(3) 芽胸の形成

GAM 半流動培地, PE-2 培地または肝肝プイョン培地 に接種した。培養 3 日後より每日培養液の一部をとり， 位相差影钽鏡を用いて,芽胞及び芽胞琵の形を観察した。

i ）棈円形芽胞 : 大部分の芽胞が明らかに円柱状また は棈円形であるとき陽性，球状であるとき陰性とした。

ii）芽胞索の膨大：大部分が影著に膨大しているとき 陽性，やや膨大しているとき及び膨大しているものと膨
大していないものが混在するとき弱陽性，すべてが明ら かに膨大していないとき陰性とした。

iii）端在芽胞：すへての芽胞が栄養細胞の最端部に形 成されているとき陽性，最端部に形成されたものと準端 部に形成されたものとが湦在するとき，及び大部分の芽 胞が準端部に形成されているとき弱陽性, 準端部に形成 されたものと中央部に形成されたものとが混在すると き，及びすべて中央部に形成されているとき陰性とした。 （4）ゼラチンの加水分解

ゼラチン培地に接種し，5 日間培養した。これを無接 種対照培地とともに $2 \sim 10^{\circ} \mathrm{C} に$ 放店し，冷却した。

供試培地を鲉立させ，対照培地が固化しているにもか かわらず，供試培地が液状のままであれば陽性，これら を室温下にもどしたとき, 対照培地が液化するのに要す る時間の半分の時間以内に供試培地が夜化すれば搦陽性 とした。これ以外のものは陰性とした。

(5) レシチナーゼ及びリパーゼの産生

卵黄寒天平板培地に前培養液 1 白金耳を画線し，4 日 間嫌気培盖 (BBL，GasPak を使用) した。

i ）レシチナーゼ：集落の周囲に白濁を生したとき陽 性，白濁が集落の直下に限られたとき及び白濁を生じな かったときは陰性とした。

ii）リパーゼ : 集落の直下にのみ白濁を生じ，かつ集 落表面に真珠様光沢を生じたとき陽性，これ以外のとき 陰性とした。

(6) 凝固卵白の液化

凝固卵白培地に接種し，30 日間培養した。卵白片が崩 壊するか，透明となったとき陽性とした。

(7) 牛乳の激しい発醰及び消化 鉄加牛乳培地に接種し，15 日間培程した。

i) 激しい発醉 : 培盖 5 日以内に牛乳が凝固し, 旺盛 なガス産生の結果，培地の夜面に気泡が積み重なったと き陽性，ガス産生能が弱く，気泡の積み重なりが認めら れなかったときには弱陽性とした。

ii）消化：ペプトン化がみられたとき陽性とした。凝 固に伴なら乳清分離は陰性とした。

（8）炭水化物からの酸産生

それぞれの炭水化物分解試験用培地に接種し，5 日間 培着した。

この培着渡及びこれと同一条件で恒温放狊した無接種 对照培地に $0.4 \%$ ブロムチモール・ブルー夜 1 〜滴を 加え，両者の色謂の美異により $\mathrm{pH}$ の変化を調ぺた。対 照培地に比較して 影著な $\mathrm{pH}$ 低下が認められたとき陽 性，わずかに低下したとき弱陽性とした。 
（9）毒素産生

クックド・ミート培地に接種し， $35^{\circ} \mathrm{C} ， 5$ 日間培養し た。

この培䖯液の上登 $0.5 \mathrm{~m} l$ をマウス（4週令, 体重的 $20 \mathrm{~g}$ ）の腹腔内に注射した。供試菌株 1 怢につきマウス 2 匹を用い，注射後 24 時間以内に 2 匹ともへい死した とき陽性とした。2 匹中の 1 匹がへい死したときには再 試験の結果により判定しだ”。

(10) $55^{\circ} \mathrm{C}$ における発育

肝肝ブイヨン培地または $\mathrm{PE}-2$ 培地に接種し， $55^{\circ} \mathrm{C}$, 5 日間培養した。

培地に発育の徵候（混濁またはガス産生）が認められ たとき陽性とした。

\section{(11) 硫酸塩の還元}

前培羡液を隇菌生理食塩水で 10 倍希积した液 $0.5 \mathrm{ml}$

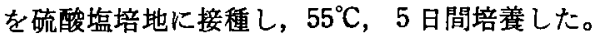

培地全体が黑変したとき陽性，これ以外のとき陰性と した。

\section{結果及び考察}

著者らが供試菌侏の同定を試み心当初，これらの生物 学的性状のうち，炭水化物の分解性は BERGEY's Manual (第 8 版 ${ }^{11}$ 記載のいずれにも該当しないものが多く，大 多数は同定できなかった。そこで，これらの菌株の同定 を金沢大学医学部微生物学教室（主任：西田台紀教授） へ依頼した。西田息は, その半数以上を Clostridium sporogenes あるいはその変異菌群と同定し，これらの 変異性は, 仵詰食品とともに笽しい加熱処理をされたこ とにより，選択あるいは変異の過程を経て得られたもの であろらと推定した。

1967 年と 1968 年に変敗ソーセージ午詰から分離した タンパク分解性嫌気性有芽胞細菌は，分離当初まったく 炭水化物を分解せず，末同定のまま著者らの研究室で保 管されてきたのであるが，継代培養を繰り返す途中で炭 水化物の分解性を調べてみたところ, ブドウ糖, 麦芽 糖，しょ糖を次第に分解するようになった（Table 1)。 これより，仟詰食品のように政しい加熱処理を経て分離 される株では，分離值後には，炭水化物の分解性が必ず しも定型的に現われないものと推察された。

供試菌株は，そのほとえどが Clostridium 属紐菌であ ろらと推定されたが, BERGEY's Manual' ${ }^{1 !}$ にって本種 を同定する湯合には炭水化物の分解性が重要な鍵になる ので，この性状が不安定であっては同定が困難である。 そこで, 従来, 変敗缶詰食品からしばしば分離されると
Table 1 Production of acid from carbohydrates by putrefactive anaerobic sporeformers isolated from spoiled canned sausages

\begin{tabular}{|c|c|c|c|c|c|c|c|}
\hline $\begin{array}{c}\text { Strain } \\
\text { No. }\end{array}$ & $\begin{array}{c}\text { Year } \\
\text { examined }\end{array}$ & 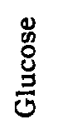 & 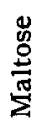 & 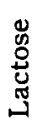 & 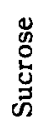 & 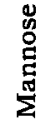 & 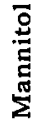 \\
\hline \multirow{3}{*}{5049} & 1967 & $-{ }^{a}$ & - & - & - & - & - \\
\hline & 1974 & + & - & - & $\mathbf{w}$ & $\mathrm{Ne}$ & - \\
\hline & 1982 & + & + & - & + & - & - \\
\hline \multirow{3}{*}{5050} & 1967 & - & - & - & - & - & - \\
\hline & 1974 & $\mathbf{w}$ & $\mathbf{w}$ & - & + & $\mathrm{Ne}$ & - \\
\hline & 1982 & + & w & - & + & - & - \\
\hline \multirow{3}{*}{5051} & 1968 & - & - & - & - & - & - \\
\hline & 1974 & - & - & - & - & $\mathrm{Ne}$ & - \\
\hline & 1982 & + & $\mathbf{w}$ & - & + & - & - \\
\hline \multirow{3}{*}{5052} & 1968 & - & - & - & - & - & - \\
\hline & 1974 & + & - & - & + & $\mathrm{Ne}$ & - \\
\hline & 1982 & + & - & - & + & - & - \\
\hline
\end{tabular}

a) + , positive; $w$, weakly positive; - negative; $\mathrm{Ne}$, not examined

言われている耐熱性偏性嫌気性有芽胞細菌の種について のみ同定することにした。選んだ種と，これらを鑑別す るために用いた性状を Table 2 に示した。Table 2 を 作成するに当っては BergeY's Manual (第 7 版") およ び第 8 版") のほか, National Canners Association の $\checkmark=ュ ア ル 10$, SPRAY ${ }^{5)}$ 及び MCClung と TOABE ${ }^{11}$ の 報告を参照し，これらに示された性状のうち，著者らの 経験から，それぞれの種の特徽が明確に現われ，かつ裁 別が容易なものを選び採用した。

供試菌株の生物学的性状を $2 \sim 3$ 回繰り返して調べ, Table 2 に基ついて同定した結果を Table 3 に示した。 生物学的性状の試験結果は, 通常は陽性 (十) または陰 性（一）のいずれかで示されるが，ここでは陽性反応を (1) 明瞭なもの(十) と(2) 微弱なもの及びそのつど変化し たもの（w/V) に分け，また陰性反応を(3)供試菌株が 培地に発育し，陰性となったもの(一)と (4) 発育しなか ったため陰性と判定されたもの (NG)に分けて示した。 これは，後日参照するのに便利であろうと考えたのと， たとえば C. thermosaccharolyticum のよ5に，弱な 牛乳の発醉を示し, 卵黄寒天培地（リパーセ及びレシチ ナーゼの産生を調べるのに用いた）上で嫌気的に発育し 
Table 2 Proposed differential criteria for the selective species of genera Clostridium and Desulfotomaculum

\begin{tabular}{|c|c|c|c|c|c|c|c|c|c|c|c|c|c|c|c|c|c|c|}
\hline \multirow[b]{2}{*}{ Species } & \multirow[b]{2}{*}{ 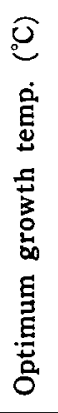 } & \multicolumn{11}{|c|}{ First step } & \multicolumn{6}{|c|}{ Second step } \\
\hline & & $\begin{array}{l}\text { 売 } \\
3 \\
0 \\
0 \\
0 \\
0 \\
0 \\
0 \\
0 \\
0 \\
0\end{array}$ & 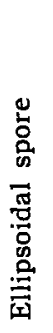 & 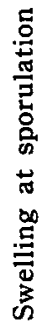 & 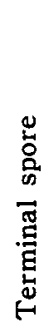 & 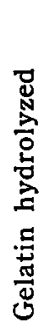 & 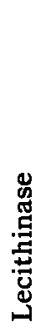 & 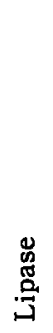 & 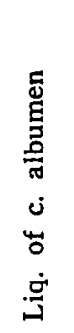 & 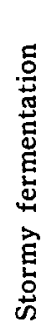 & 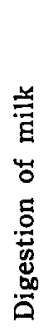 & 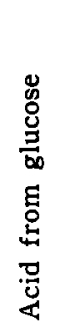 & 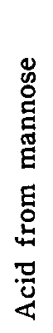 & 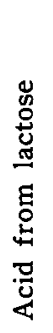 & 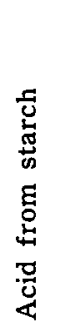 & 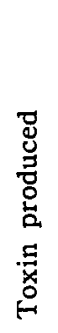 & $\begin{array}{l}0 \\
\text { in } \\
10 \\
+ \\
+0 \\
5 \\
5 \\
0 \\
0 \\
0\end{array}$ & 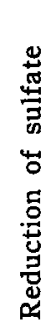 \\
\hline C. sporogenes & 35 & -a) & + & + & $\mathrm{V}$ & + & - & + & + & - & + & + & & & & - & & \\
\hline C. botulinum & 35 & - & + & + & $\mathrm{V}$ & + & - & + & + & - & + & + & & & & + & & \\
\hline C. bifermentans & 35 & - & + & - & - & + & + & - & $+/ w$ & - & + & + & & - & & & & \\
\hline C. perfringens & 35 & - & + & - & - & + & + & - & - & + & - & + & & + & & & & \\
\hline C. butyricum & 35 & - & + & $\mathrm{V}$ & $\mathrm{V}$ & - & - & - & - & + & - & + & + & + & + & & & \\
\hline C. pasteurianum & 35 & - & + & $\mathrm{V}$ & $\mathrm{V}$ & - & - & - & - & - & - & + & + & - & - & & & \\
\hline C. thermosaccharolyticum ${ }^{\mathrm{b})}$ & 55 & - & - & + & + & - & & & - & $\mathbf{w}$ & - & + & & & & & + & - \\
\hline D. nigrificans & 55 & - & $\mathrm{V}$ & $\mathrm{V}$ & - & - & & & - & - & - & - & & & & & + & + \\
\hline
\end{tabular}

a) V, variable. See Table 1 for the other symbols.

b) Gram stain is usually negative.

ないのがぞの種の特改とみられる菌種が含まれていた ためである (Table 3)。

このような方法により，供試 122 株中の 99 株（81\%) を同定することができた。これらの圧到的多数をC. sporogenes が占め, 本種は 65 株であった。次いでC. thermosaccharolyticum 14 株, C. pasteurianum 11 株, Desulfotomaculum nigrificans 4 株, C. butyricum 3 株, C. perfringens 2 株の順であった。

残る 23 株中の 10 株は, いずれるミルク・コーヒー缶 詰としるこ午詰から分離された特徽ある高温性有芽胞細 菌で，その芽胞の熱抵抗力が極端に強く，単一種である らと推定されたのでささらに詳細に性状を調べ, BERGEY's Manual (第 7 版) ${ }^{9}$ 記载の $C$. thermoaceticum と同定 した。C. thermoaceticum の性状の詳練については既 辄12)に述べた。最後に13 株が残ったが，これらはそれ ぞれに性状が異なり，さしたる特凗むなかったので末同 定のままにした。

AscheHOUG と JANSEN ${ }^{18)}$ は, ノルウェ一産の变敗魚類 仵詰から分離したタンパク分解性䍅気性有芽胞細菌 46
株中の 38 株が C. sporogenes 類似菌であったと報告し ているが，この結果は本報告とよく一致する。熊倉ら ${ }^{14)}$ は, わが国産の各種缶詰食品の変敗事故の5ち, Clostridium 属細菌仁起因するもの 22 例を分析 L，C. bifermentans Кよるものが 2 例, C. sporogenes 2 例, C. thermosaccharolyticum 2 例, C. pasteurianum 2 例, C. perfringens 1 例, C. toanum 2 例, C. tale 1 例, 同定不能 10 例であったと報告している。熊倉ら ${ }^{14)}$ の報 告に同定不能の事故例が多いのは, 午詰由来の菌株に非 定型の性状を示するのが多いことによると思われる。な お，彼らか同定した C. toanum と C. tale は, BERGEY's Manual (第 8 版) $)^{1}$ において削除されている。

すでに西田(15)は，C. perfringens およびC. novyiで は，加熱によって生物学的性状の異なる非定型菌侏が現 われることを述べている。䍌食品由来の Clostridium 属細菌は相当䈗しい加熱処理を受けているはずであるか ら，非定型的な菌株が現われることは当然予湘される。 したがって，㓡詰食品由来の菌株を現在一般的に用いら れているような方法により鑑別したのでは，種名を誤る 
Table 3 Characteristics of strains of genera Clostridium and Desulfotomaculum isolated from spoiled canned foods

\begin{tabular}{|c|c|c|c|c|c|c|c|c|c|c|c|c|c|c|c|c|c|c|c|}
\hline Species & 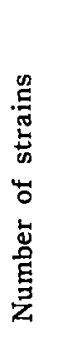 & 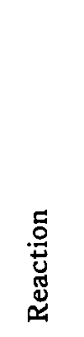 & 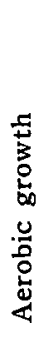 & 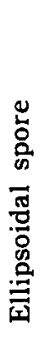 & 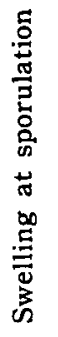 & 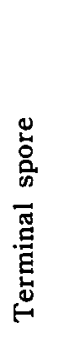 & 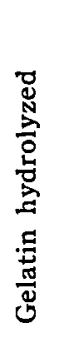 & 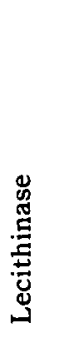 & 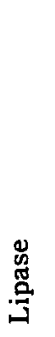 & 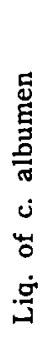 & 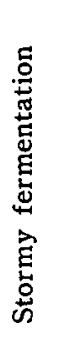 & 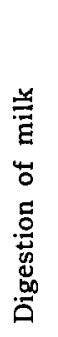 & 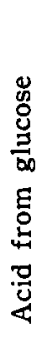 & 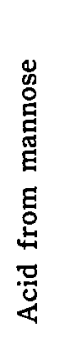 & 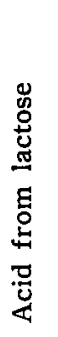 & 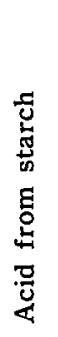 & 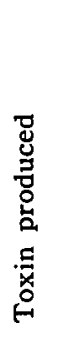 & 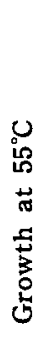 & 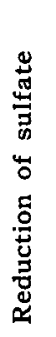 \\
\hline \multirow{4}{*}{ C. sporogenes } & \multirow{4}{*}{65} & $+^{a)}$ & $0^{b)}$ & 65 & 64 & 4 & 65 & $\mathbf{0}$ & 64 & 65 & 0 & 65 & 49 & \multirow{4}{*}{$\mathrm{Ne}^{\mathrm{a})}$} & \multirow{4}{*}{$\mathrm{Ne}$} & \multirow{4}{*}{$\mathrm{Ne}$} & 0 & \multirow{4}{*}{$\mathrm{Ne}$} & \multirow{4}{*}{$\mathrm{Ne}$} \\
\hline & & $\mathrm{w} / \mathrm{V}$ & 0 & 0 & 1 & 57 & 0 & 0 & 1 & 0 & 0 & 0 & 9 & & & & 0 & & \\
\hline & & - & 0 & 0 & 0 & 4 & 0 & 65 & 0 & 0 & 65 & 0 & 7 & & & & 65 & & \\
\hline & & NG & 65 & 0 & 0 & 0 & 0 & 0 & 0 & 0 & 0 & 0 & 0 & & & & 0 & & \\
\hline \multirow{4}{*}{ C. perfringens } & \multirow{4}{*}{2} & + & 0 & 2 & 0 & 0 & 2 & 2 & 0 & 0 & 2 & 0 & 2 & 2 & 2 & 2 & \multirow{4}{*}{$\mathrm{Ne}$} & \multirow{4}{*}{$\mathrm{Ne}$} & \multirow{4}{*}{$\mathrm{Ne}$} \\
\hline & & $\mathrm{w} / \mathrm{V}$ & 0 & 0 & 0 & 0 & 0 & 0 & 0 & 0 & 0 & 0 & 0 & 0 & 0 & 0 & & & \\
\hline & & - & 0 & 0 & 2 & 2 & 0 & 0 & 2 & 2 & 0 & 2 & 0 & 0 & 0 & 0 & & & \\
\hline & & NG & 2 & 0 & 0 & 0 & 0 & 0 & 0 & 0 & 0 & 0 & 0 & 0 & 0 & 0 & & & \\
\hline \multirow{4}{*}{ C. butyricum } & \multirow{4}{*}{3} & + & 0 & 3 & 0 & 0 & 0 & 0 & 0 & 0 & 3 & 0 & 3 & 3 & 3 & 3 & \multirow{4}{*}{$\mathrm{Ne}$} & \multirow{4}{*}{$\mathrm{Ne}$} & \multirow{4}{*}{$\mathrm{Ne}$} \\
\hline & & $\mathrm{w} / \mathrm{V}$ & 0 & 0 & 1 & 2 & 0 & 0 & 0 & 0 & 0 & 0 & 0 & 0 & 0 & 0 & & & \\
\hline & & - & 0 & 0 & 2 & 1 & 3 & 3 & 3 & 3 & 0 & 3 & 0 & 0 & 0 & 0 & & & \\
\hline & & NG & 3 & 0 & 0 & 0 & 0 & 0 & 0 & 0 & 0 & 0 & 0 & 0 & 0 & 0 & & & \\
\hline \multirow{4}{*}{ C. pasteurianum } & \multirow{4}{*}{11} & + & 0 & 11 & 4 & 0 & 0 & 0 & 0 & 0 & 0 & 0 & 11 & 11 & 0 & 0 & \multirow{4}{*}{$\mathrm{Ne}$} & \multirow{4}{*}{$\mathrm{Ne}$} & \multirow{4}{*}{$\mathrm{Ne}$} \\
\hline & & $\mathrm{w} / \mathrm{V}$ & 0 & 0 & 2 & 3 & 0 & 0 & 0 & 0 & 0 & 0 & 0 & 0 & 0 & 0 & & & \\
\hline & & - & 0 & 0 & 5 & 8 & 11 & 2 & 2 & 11 & 11 & 11 & 0 & 0 & 0 & 0 & & & \\
\hline & & NG & 11 & 0 & 0 & 0 & 0 & 9 & 9 & 0 & 0 & 0 & 0 & 0 & 11 & 11 & & & \\
\hline \multirow{4}{*}{$\begin{array}{l}\text { C. thermo- } \\
\text { saccharolyticum }\end{array}$} & \multirow{4}{*}{14} & + & 0 & 0 & 14 & 14 & 0 & 0 & 0 & 0 & 0 & 0 & 14 & 14 & 14 & 14 & & 14 & 0 \\
\hline & & $\mathbf{w} / \mathrm{V}$ & 0 & 0 & 0 & 0 & 0 & 0 & 0 & 0 & 14 & 0 & 0 & 0 & 0 & 0 & \multirow{3}{*}{$\mathrm{Ne}$} & 0 & 0 \\
\hline & & - & 0 & 14 & 0 & 0 & 14 & 0 & 0 & 14 & 0 & 14 & 0 & 0 & 0 & 0 & & 0 & 14 \\
\hline & & NG & 14 & 0 & 0 & 0 & 0 & 14 & 14 & 0 & 0 & 0 & 0 & 0 & 0 & 0 & & 0 & 0 \\
\hline & & + & 0 & 0 & 10 & 10 & 0 & 0 & 0 & 0 & 0 & 0 & 2 & 0 & 0 & 0 & & 10 & 0 \\
\hline C. thermoaceticum & 10 & $\mathrm{w} / \mathrm{V}$ & 0 & 0 & 0 & 0 & 0 & 0 & 0 & 0 & 0 & 0 & 7 & 5 & 0 & 0 & $\mathrm{Ne}$ & 0 & 0 \\
\hline 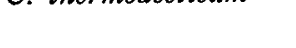 & & - & 0 & 10 & 0 & 0 & 0 & 0 & 0 & 5 & 10 & 10 & 1 & 4 & 5 & 5 & & 0 & 10 \\
\hline & & NG & 10 & 0 & 0 & 0 & 10 & 10 & 10 & 5 & 0 & 0 & 0 & 1 & 5 & 5 & & 0 & 0 \\
\hline & & + & 0 & 4 & 0 & 0 & 0 & 0 & 0 & 0 & 0 & 0 & 0 & 2 & 0 & 0 & & 4 & 4 \\
\hline & & $\mathrm{w} / \mathrm{V}$ & 0 & 0 & 4 & 0 & 0 & 0 & 0 & 0 & 0 & 0 & 3 & 1 & 1 & 1 & $\mathrm{Ne}$ & 0 & 0 \\
\hline (and & & - & 0 & 0 & 0 & 4 & 3 & 0 & 0 & 4 & 4 & 4 & 1 & 1 & 3 & 3 & & 0 & 0 \\
\hline & & NG & 4 & 0 & 0 & 0 & 1 & 4 & 4 & 0 & 0 & 0 & 0 & 0 & 0 & 0 & & 0 & 0 \\
\hline
\end{tabular}

a) NG, no growth. See Tables 1 and 2 for the other symbols.

b) Number of strains 
Table 4 Simplified formulae for differential identification of commonly encountered species of genera Clostridium and Desulfotomaculum in canned food spoilage

\begin{tabular}{|c|c|c|c|c|c|c|c|c|c|c|c|c|}
\hline \multirow[b]{2}{*}{ Species } & \multirow[b]{2}{*}{ 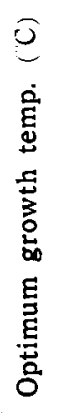 } & \multicolumn{8}{|c|}{ First step } & \multicolumn{3}{|c|}{ Second step } \\
\hline & & 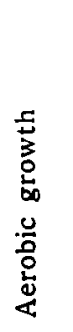 & 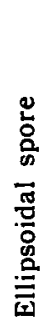 & 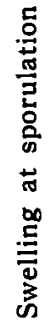 & 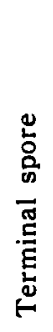 & 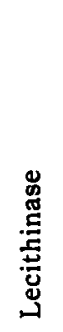 & 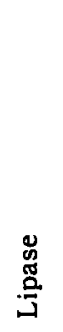 & 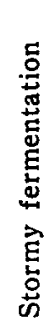 & 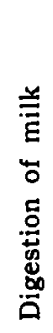 & 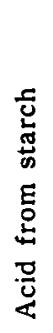 & 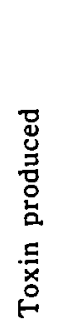 & 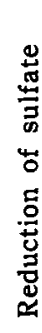 \\
\hline C. sporogenes & 35 & $-2)$ & + & + & $\mathrm{V}$ & - & + & - & + & & - & \\
\hline C. botulinum & 35 & - & + & + & $\mathbf{v}$ & - & + & - & + & & + & \\
\hline C. bifermentans & 35 & - & + & - & - & + & - & - & + & & & \\
\hline C. perfringens & 35 & - & + & - & - & + & - & + & - & & & \\
\hline C. butyricumb) & 35 & - & + & V & V & - & - & + & - & + & & \\
\hline C. pasteurianumb) & 35 & - & + & $\mathrm{V}$ & V & & NG & - & - & - & & \\
\hline C. thermosaccharolyticumc) & 55 & - & - & + & + & NG & $N G$ & $\mathbf{w}$ & - & + & & - \\
\hline C. thermoaceticum ${ }^{\mathrm{d}}$ & 55 & - & - & + & + & NG & NG & - & - & & & - \\
\hline D. nigrificans & 55 & - & V & V & - & NG & NG & - & - & & & + \\
\hline
\end{tabular}

a) See Tables 1, 2 and 3.

b) Abundant growth in juice made of tomato or orange ( $\mathrm{pH} 4.5$ )

c) Usually Gram negative

d) Fresh spores survive after autoclaving for 20 minutes at $120^{\circ} \mathrm{C}$.

か,あるいは末同定として残すかのいずれかにならざる をえない。

商㮍的に製造された缶詰食品に变敗事故が発生したと きには迅速な対们か:要求される。このようなとき，変敗 原因菌の種名を BeRGEY's Manual (第 8 版) ${ }^{\prime}$ 記载の有 芽胸細菌 115 種 (Bacillus 属 48 種, Clostridium 属 61 瘇, Sporolactobacillus 属 1 種，Desulfotomaculum 属 3 種, Sporosarcina 属 2 種) の中から捜し出すのは容 易なことではない。敩し!加熱処理を受けたことによっ て性状が不安定になっている菌株であれば一層困難であ る。変敗事故の再発防止のためには，過去に報告された 变敗原因菌との願似性を把握するたけでる有益である。 そこで, Table 3 の結果に基づ，変敗午詰由来偏性娧 気性有芽胞細菌の簡易踏別表（Table 4) を作成した。 著者らの分離菌株中にC. bifermentans は含まれてい なかったが，過去の報告1416117に多いので, Table 4 に はこれを含めた。
要 䄪

变敗午詰から分崔した偏性媒気性有芽胞細菌 122 株を 簡易法により同定したところ 99 株 $(81 \%)$ を同定するこ とができた。これらはC. sporogenes 65 株，C. thermosaccharolyticum 14 株, C. pasteurianum 11 株, D. nigrificans 4 株, C. butyricum 3 , C. perfringens 2 株であった。簡易法により同定できなかった 23 株の らち 10 株は C. thermaaceticumであった。

得られた結果に基づき，变敗缶詰由来偏性娧気性有芽 胞細菌の简易鏃別表を作成した。本表によれば，発育最 商温度，好気的発育，芽胞及び芽胞鉒の形、レシチナー ゼ及びリハーゼの産生，牛乳の発酵及び消化の汪か，必

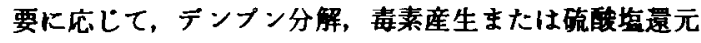
のいずれかを調へることにより変敗原因菌を路でき る。 
本研究において有益な御助言をいたたいた金沢大学医 学部西田向紀教授と，原稿を御校閲いただいた東京農業 大学小崎道雄教授に深謝する。

\section{文献}

1) Gibson, T., Gordon, R. E., Kitahara, K., Smith, L. DS., HobBs, G. and CAMpbell, L. L. : Bergey's Manual of Determinative Bacteriology, 8th ed., Buchanan, R.E. and Gibons, N. E. edited (The Williams and Wilkins Co., Baltimore), p. 529 (1974).

2）松田典彦・駒木 勝・市川良子・後藤幸恵：日食 工誌, 32, 444 (1985).

3) Gordon, R. E., Haynes, W.C. and Hor-Nay PANG, C.: The Genus Bacillus, Agriculture Handbook No. 427 (U.S.D.A., Washington, D. C.), p. 101 (1973).

4) Hersom, A.C. and Hulland, E. D.: Canned Foods, an introduction to their microbiology, 5th ed. (J. A. Churchill Ltd., London), p. 323 (1963).

5) SPRAY, R.A.: J. Bacteriol., 32, 135 (1936).

6) American Type Culture Collection: The American Type Culture Collection, Catalogue of Strains, 10th ed. (American Type Culture Collection, Maryland), p. 238 (1972).

7）阪口玄二：微生物検查必茎，厚生省監修（日本公
衆衛生協会, 東京), p. 209 (1966).

8）西田尚紀：食衛誌，17，1（1976）.

9) Breed, R. S., Murray, E. G. D. and SMith, N.R.: Bergey's Manual of Determinative Bacteriology, 7th ed. (The Williams and Willkins Co., Baltimore), p. 613 (1957).

10) National Canners Association, Research Laboratories: Laboratory Manual for Food Canners and Processors, 3rd ed., Vol. I (The AVI Publ. Co., Inc., Westport, Connecticut), p. 117 (1968).

11) McClung, L.S. and Toabe, R.: J. Bacteriol., 53, 139 (1947).

12）松田典彦・増田寛行 - 駒木 勝 - 松本直起：食衛 誌, 23, 480 (1982).

13) Aschenoug, V. and Jansen, E.: Food Research, 15, 62 (1950).

14）熊倉 悟 - 田中昭二・茂木幸夫：午詰時報，37 (12), 62 (1958) .

15) 西田䏌紀：日細誌，31，663(1976)。

16）田中昭二：年詰時報，41(2)，39 (1962).

17) Walker, H.W.: Food Microbiology, Public Health and Spoilage Aspects, DifigueIREdo, M. P. and Splitlstoesser, D.F. edited (The AVI Publ., Co., Inc., Westport, Connecticut), p. 373 (1976).

(昭和 59 年 8 月 28 日受理) 